\title{
PENELITIAN
}

\section{UJI COBA MODEL PENDETEKSIAN TERHADAP PENGANIAYAAN USIA LANJUT DI KELUARGA*}

\author{
Etty Rekawati, Widyatuti, Poppy Fitriyani***
}

\begin{abstract}
Abstrak
Tujuan penelitian ini adalah tersusunnya model pendeteksian terhadap penganiayaan usia lanjut di keluarga. Desain yang digunakan dalam penelitian ini adalah riset operasional, yang pelaksanaannya pada tahap I desain yang digunakan adalah eksploratif, pada tahap II menggunakan desain konfirmatif dan tahap III pengambilan data untuk mengidentifikasi masalah penganiayaan usia lanjut di keluarga. Sampel yang digunakan 11 petugas kesehatan dan 44 usia lanjut yang tinggal di keluarga yang dipilih secara acak di Kecamatan X di wilayah Jakarta Timur. Berdasarkan analisis data diperoleh hasil: instrumen yang digunakan pada penelitian ini didapatkan nilai kevalidan sebesar 0,6900 - 0,7378 yang merupakan nilai lebih dari nilai $\mathrm{r}$ tabel $(\mathrm{r}=0,288)$, ini menyatakan bahwa hubungan antar pertanyaan dengan nilai keseluruhan instrument cukup baik, dengan realibilitas (menggunakan $\alpha$-cronbah) sebesar 0,7275 . Masalah penganiayaan yang ditemukan adalah sebesar 18,18\% usia lanjut di keluarga mengalami penganiayaan fisik, $97,73 \%$ penganiayaan emosi, $13,64 \%$ penganiayaan seksual, $31,82 \%$ penganiayaan ekonomi/finansial, $61,36 \%$ pengabaian dan $29,55 \%$ mengalami penelantaran. Usia lanjut yang sering mengalami penganiayaan yaitu yang berumur 60 - 75 tahun, berjenis kelamin perempuan, bersuku bangsa Jawa, Agama Islam, tingkat pendidikan SD dan sudah berstatus janda/duda. Model ini dapat digunakan pendeteksian terhadap penganiayaan usia lanjut secara dini sehingga bagi usia lanjut yang sudah terdeteksi dianiaya oleh keluarga dapat dilakukan penanganan secepatnya.
\end{abstract}

Kata kunci: keluarga, pendeteksian, penganiayaan, usia lanjut

\begin{abstract}
The purpose of the study was to arrange detection model of elderly abuse in family. This study used operational research that first stage use eksploratif, second stage use confirmative design, and third stage was data collection to identify elderly abuse in family. Sample that was taken are 11 health staff and 44 elderlies who live in family and randomly chosen. The area of this study was in $X$ district, East Jakarta. The result of this study indicated that validity value is 0,6900-0,7378 (r table =0,288) with reability (use $\alpha$-cronbah) is 0,7275. This study showed that 18,18\% of elderly have physical abuse, 97,73\% have emotional abuse, 13,64\% have sexual abuse, 31,82\% have economic/ financial abuse, 61,36\% neglect and 29,55\% abandon. The elderly that tend to be abused ranges about 60-75 years old, women, Javanese, Islamic, level of education background is primary school, widow/widower. This study can be used to detect elderly abuse as early as possible to improve elderly welfare in community.
\end{abstract}

Key words: abuse, detection, elderly, family

\section{LATAR BELAKANG}

Keberadaan usia lanjut dalam suatu keluarga dapat mempengaruhi fungsi keluarga yang selanjutnya turut menentukan kemampuan keluarga dalam menghadapi dampak proses transisi dari masyarakat industri modern (Skolniek, 1987). Keluarga sebagai orang terdekat dengan usia lanjut diharapkan mampu memfasilitasi usia lanjut agar dapat menghadapi dan melaksanakan tugas perkembangannya. Namun pada kenyataannya keluarga mempunyai kesibukan tersendiri sehingga dapat saja melupakan keberadaan usia lanjut yang tinggal di keluarga.

Penganiayaan usia lanjut di keluarga diartikan sebagai ketidakmampuan keluarga dalam melakukan perawatan secara fisik, psikologis dan 
sosial terhadap usia lanjut yang tinggal serumah. Ketidakmampuan keluarga dalam memenuhi kebutuhan usia lanjut secara fisik, psikologis, sosial dan spiritual akan mengakibatkan terlantarnya usia lanjut. Amendments to the Older Americans Act (1987) menyatakan bahwa penelantaran usia lanjut merupakan salah satu dari penganiayaan pada usia lanjut. Dari tahun 1986 sampai dengan 1996 terjadi peningkatan angka kejadian penganiayaan terhadap usia lanjut, tahun 1986 dilaporkan sebesar 117.000 penganiayaan, 128.000 kasus pada tahun 1987 , 140.000 kasus dilaporkan pada tahun 1988, 211.000 laporan di tahun 1990, 213.000 laporan di tahun 1991, 227.000 laporan di tahun 1993, 241.000 laporan di tahun 1994, 286.000 tahun 1995, dan 293.000 di tahun 1996 (Duckhorn, 1997).

Amendments to the Older Americans Act (1987) menyatakan bahwa penelantaran usia lanjut merupakan salah satu dari penganiayaan pada usia lanjut. Dari tahun 1986 sampai dengan 1996 terjadi peningkatan angka kejadian penganiayaan terhadap usia lanjut, tahun 1986 dilaporkan sebesar 117.000 penganiayaan, 128.000 kasus pada tahun 1987, 140.000 kasus dilaporkan pada tahun 1988 , 211.000 laporan di tahun 1990, 213.000 laporan di tahun 1991, 227.000 laporan di tahun 1993, 241.000 laporan di tahun 1994, 286.000 tahun 1995, dan 293.000 di tahun 1996 (Duckhorn, 1997).

Tipe dari penganiayaan pada usia lanjut (Duckhorn, 1997) menjabarkan bahwa sebesar $14,6 \%$ terjadi penganiayaan fisik, $12,396 \%$ terjadi penganiayaan finansial, $7,796 \%$ terjadi penganiayaan emosi, 0,396 terjadi penganiayaan seksual, $55,096 \%$ terjadi pengabaian terhadap usia lanjut, $4,096 \%$ tidak diketahui dan $6,196 \%$ terjadi penganiayaan lainnya.

Tenaga kesehatan menyadari bahwa penganiayaan usia lanjut di keluarga mulai banyak terjadi di masyarakat kita. Dan masalah ini tidak terdeteksi karena kejadian penganiayaan usia lanjut sering kali tidak disadari baik oleh pelaku maupun oleh penderita. Dan sampai dengan saat ini masih belum terdapat alat ukur yang dapat mendeteksi penganiayaan usia lanjut di keluarga, sehingga sulit untuk menentukan penganiayaan tersebut. Untuk itu peneliti tertarik untuk mengembangkan model deteksi terhadap penganiayaan usia lanjut di keluarga, sehingga dapat dilakukannya pendeteksian secara dini terhadap penganiayaan usia lanjut di keluarga yang pada akhirnya akan menurunkan angka kesakitan usia lanjut.

\section{METODOLOGI}

Desain yang digunakan adalah riset operasional, pelaksanaannya dibedakan dalam 3 tahap sebagai berikut: Tahap 1 adalah Pengembangan Model, desain yang digunakan adalah Eksploratif. Tahap 2 adalah Validasi Model, desain yang digunakan adalah Konfirmatif (uji coba) melalui pelatihan yang ditujukan kepada penanggung jawab Program Perawatan Kesehatan Masyarakat dan Program Kesehatan Usia lanjut di wilayah Kecamatan Pulo Gadung Jakarta Timur, yang bertujuan untuk mengujicobakan model pendeteksian penganiayaan usia lanjut di keluarga, diikuti dengan supervisi sebanyak empat kali untuk memantau ketrampilan petugas di dalam mendeteksi penganiayaan usia lanjut di keluarga. Tahap 3 adalah Analisis Masalah Penganiayaan, desain yang digunakan pada tahap ini adalah deskriptif yang bertujuan untuk mengidentifikasi masalah penganiayaan usia lanjut di keluarga.

\section{HASIL}

Instrumen pendeteksian terdiri dari 3 format, format 1 adalah Instrumen pengkajian kesehatan. Pengkajian kesehatan dilakukan oleh petugas kesehatan melalui pemeriksaan fisik dan pemeriksaan psiko sosial usia lanjut. Format kedua adalah Instrumen Wawancara kepada usia lanjut. Wawancara dilakukan oleh petugas kesehatan dengan cara memberikan beberapa pertanyaan pada usia lanjut. Format ketiga adalah Instrumen wawancara kepada keluarga. Wawancara dilakukan oleh petugas kesehatan dengan cara memberikan pertanyaan pada keluarga. 
Ketiga instrumen tersebut merupakan alat ukur untuk mendeteksi penganiayaan usia lanjut di keluarga. Petugas kesehatan dalam hal ini adalah Perawat Kesehatan Masyarakat melakukan pendeteksian terhadap penganiayaan terhadap usia lanjut di keluarga dengan melakukan kunjungan rumah pada usia lanjut yang tinggal dengan keluarganya yang berada di wilayah binaannya. Instrumen yang dibekali oleh petugas kesehatan adalah hanya sebatas deteksi dini terhadap penganiayaan, dan apabila petugas kesehatan menemukan penganiayaan pada usia lanjut di keluarga, perlu dikembangkan lebih jauh bagaimana cara mengatasi penganiayaan tersebut.

Format 1, 2, dan 3 setelah diuji dengan korelasi Pearson nilai kevalidan dari instrument yang dibuat antara 0,6900 - 0,7378 yang merupakan nilai lebih nilai $r$ tabel $(r=0,288)$, ini menyatakan bahwa hubungan antar pertanyaan dengan nilai keseluruhan instrument cukup baik, dengan realibilitas (menggunakan $\alpha$-cronbah) sebesar 0,7275, yang artinya adalah pertanyaan-pertanyaan dalam instrument tersebut cukup konsisten (Polit \& Hungler, 2002).

Pelatihan dimulai dengan dilakukannya test awal terhadap pengetahuan petugas kesehatan yang berjumlah 11 orang, mengenai penganiayaan pada usia lanjut dan diakhiri dengan test akhir untuk melihat sejauh mana tingkat keberhasilan pelatihan dalam meningkatkan pengetahuan petugas kesehatan terhadap penganiayaan usia lanjut. Di bawah ini ditampilkan hasil statistik test awal dan test akhir terhadap pelatihan petugas:

Tabel 1

Hasil Test Awal dan Test Akhir Pelatihan Petugas Kesehatan Kecamatan X, Jakarta Timur

Oktober, $2003(\mathrm{p}<0,05)$

\begin{tabular}{l|c|c|c|c}
\hline & Mean & SD & $\mathrm{T}$ & $\mathrm{p}$ \\
\hline Pre test & 5,00 & 0,429 & \multirow{2}{*}{4,847} & 0,001 \\
\cline { 1 - 3 } Post test & 7,27 & 0,237 & & \\
\hline
\end{tabular}

Tabel 1 menunjukkan bahwa ada perbedaan bermakna terhadap pelatihan yang dilakukan untuk petugas kesehatan dimana nilai $\mathrm{p}<0,05$.

Setelah dilakukan pelatihan, petugas kesehatan didampingi oleh peneliti melakukan pendeteksian terhadap penganiayaan usia lanjut di keluarga. Pendeteksian ini hanya dilakukan oleh petugas kesehatan yang telah dilatih. Sebagai Gold Standar pada penelitian ini adalah peneliti sendiri.

Hasilnya sebagai berikut:

1. Data Demografi Usia Lanjut

Tabel 2

Distribusi Usia Lanjut berdasarkan data Demografi Kecamatan X, Jakarta Timur Oktober, 2003

\begin{tabular}{l|c|c}
\hline \multicolumn{1}{c|}{ Data Demografi } & Jumlah & Persentase (\%) \\
\hline 1. Umur & & \\
- 65 - 75 & 29 & 65,91 \\
- 76 - 80 & 10 & 22,73 \\
->80 & 5 & 11,36 \\
2. Suku Bangsa & 18 & 40,91 \\
- Jawa & 4 & 9,1 \\
- Sunda & 13 & 29,5 \\
- Betawi & 1 & 2,3 \\
- Batak & 6 & 13,6 \\
- Padang & 1 & 2,3 \\
- Melayu & 1 & 2,3 \\
- Tionghoa & & \\
3. Agama & 43 & 97,7 \\
- Islam & 1 & 2,3 \\
- Katolik & & \\
4. Jenis Kelamin & 17 & 38,6 \\
- Laki-laki & 27 & 61,4 \\
- Perempuan & & \\
5. Status Perkawinan & 28 & 63,6 \\
- Janda/Duda & 16 & 36,4 \\
- Menikah & & \\
6. Riwayat Pendidikan & 14 & 31,8 \\
- Tidak Sekolah & 14 & 31,8 \\
- SD & 7 & 15,9 \\
- SMP & 6 & 13,6 \\
- SMU & 3 & 6,8 \\
- Perguruan Tinggi & & \\
\hline
\end{tabular}


Tabel 2 menunjukkan bahwa sebagian besar usia lanjut berusia 60-75 tahun, bersuku bangsa Jawa, beragama Islam, berjenis kelamin perempuan, status perkawinan janda/duda, berpendidikan tidak bersekolah dan SD.

\section{Jenis Penganiayaan}

Tabel 3

Distribusi Penganiayaan pada Usia Lanjut

Kecamatan X, Jakarta Timur

Oktober, 2003

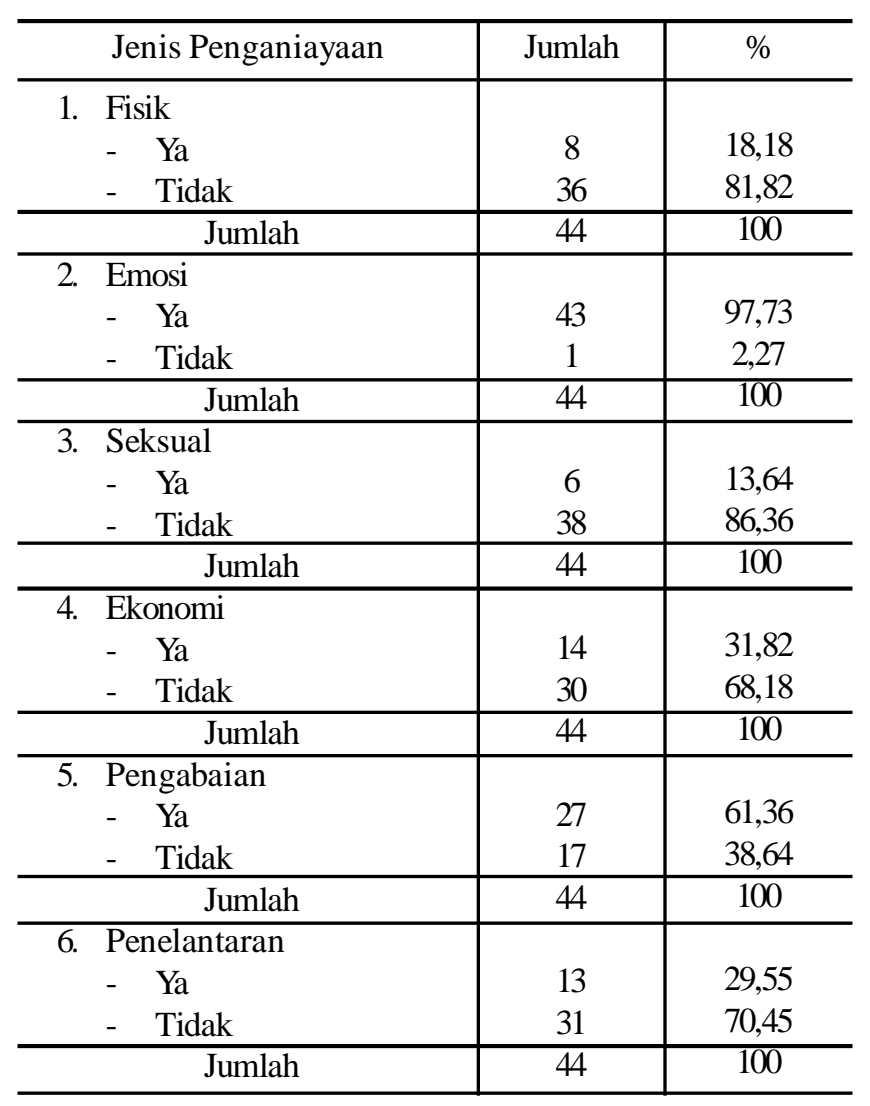

Tabel 3 menunjukan bahwa sebesar 18,18\% usia lanjut di keluarga mengalami penganiayaan fisik, 97,73\% penganiayaan emosi, $13,64 \%$ penganiayaan seksual, $31,82 \%$ penganiayaan ekonomi/finansial, $61,36 \%$ pengabaian dan $29,55 \%$ mengalami penelantaran.
Tabel 4

Jenis Penganiayaan dengan Karakteristik Usia Lanjut Kecamatan X, Jakarta Timur

Oktober, 2003 ( $\mathrm{n}=44$ )

\begin{tabular}{|c|c|c|c|c|c|c|c|}
\hline \multirow[b]{2}{*}{ No. } & \multirow[b]{2}{*}{$\begin{array}{l}\text { Karakteristik Usia } \\
\text { Lanjut. }\end{array}$} & \multicolumn{6}{|c|}{ Jenis Penganiayaan (\%) } \\
\hline & & Fisik & Sexual & $\begin{array}{c}\text { Finan } \\
\text { sial }\end{array}$ & Emosi & $\begin{array}{l}\text { Peng- } \\
\text { abaian }\end{array}$ & $\begin{array}{l}\text { Penelan- } \\
\text { taran }\end{array}$ \\
\hline \multirow[t]{4}{*}{1.} & Umur : & & & & & & \\
\hline & - $60-75$ tahun & 13,6 & 6,8 & 27,2 & 65,9 & 45,4 & 15,9 \\
\hline & - 76 - 80 tahun & 4,5 & 6,8 & 4,5 & 22,7 & 9,0 & 9,0 \\
\hline & $->80$ tahun & 2,2 & 0 & 4,5 & 11,3 & 4,5 & 4,5 \\
\hline \multirow[t]{3}{*}{2.} & Jenis Kelamin: & & & & & & \\
\hline & - Pria & 4,5 & 2,2 & 13,6 & 38,6 & 29,5 & 6,8 \\
\hline & - Wanita & 15,9 & 11,3 & 22,7 & 61,3 & 34,0 & 22,7 \\
\hline \multirow[t]{8}{*}{3.} & Suku Bangsa: & & & & & & \\
\hline & - Jawa & 11,36 & 6,8 & 18,1 & 38,6 & 31,8 & 11,3 \\
\hline & - Sunda & 0 & 0 & 4,5 & 9,0 & 6,8 & 0 \\
\hline & - Betawi & 4,5 & 4,5 & 4,5 & 29,5 & 6,8 & 11,3 \\
\hline & - Batak & 0 & 0 & 2,2 & 2,2 & 2,2 & 0 \\
\hline & - Padang & 4,5 & 2,2 & 6,8 & 13,6 & 11,3 & 4,5 \\
\hline & - Melayu & 0 & 0 & 0 & 2,2 & 2,2 & 0 \\
\hline & - Tionghoa & 0 & 0 & 0 & 2,2 & 0 & 0 \\
\hline \multirow[t]{3}{*}{4.} & Agama: & & & & & & \\
\hline & - Islam & 20,4 & 13,6 & 36,3 & 97,7 & 63,6 & 29,5 \\
\hline & - Katolik & 0 & 0 & 0 & 2,2 & 0 & 0 \\
\hline \multirow[t]{6}{*}{5.} & Pendidikan: & & & & & & \\
\hline & - Tidak Sekolah & 6,8 & 4,5 & 6,8 & 31,8 & 11,3 & 9,0 \\
\hline & $-\mathrm{SD}$ & 9,0 & 4,5 & 15,9 & 31,8 & 20,4 & 9,0 \\
\hline & - SMP & 4,5 & 4,5 & 9,0 & 15,9 & 13,6 & 4,5 \\
\hline & - SMA & 0 & 0 & 4,5 & 13,6 & 13,6 & 4,5 \\
\hline & - PT & 0 & 0 & 0 & 6,8 & 4,5 & 2,2 \\
\hline \multirow[t]{3}{*}{6.} & Status Perkawinan: & & & & & & \\
\hline & - Janda/Duda & 11,3 & 6,8 & 22,7 & 63,6 & 31,8 & 20,4 \\
\hline & - Nikah & 9,0 & 6,8 & 13,6 & 36,3 & 31,8 & 6,8 \\
\hline
\end{tabular}

Tabel 4 menyatakan bahwa usia lanjut yang sering mengalami penganiayaan pada penelitian ini yaitu yang berumur 60 - 75 tahun, berjenis kelamin perempuan, bersuku bangsa Jawa, Agama Islam, tingkat pendidikan SD dan sudah berstatus janda/duda.

\section{PEMBAHASAN}

Dari hasil analisis data penelitian terhadap instrumen yang digunakan pada penelitian ini didapatkan nilai kevalidan sebesar 0,6900-0,7378 yang merupakan nilai lebih dari nilair tabel $(r=0,288)$. Ini menunjukkan bahwa hubungan antar pertanyaan dengan nilai keseluruhan instrument cukup baik, dengan realibilitas (menggunakan $\alpha$-cronbah) sebesar 0,7275 , yang artinya adalah pertanyaan-pertanyaan dalam instrument tersebut cukup 
konsisten, sehingga instrumen yang disusun dapat digunakan sebagai suatu alat pendeteksian terhadap penganiayaan usia lanjut di keluarga.

Dari hasil pelatihan terhadap petugas kesehatan terhadap test awal dan test akhir didapatkan data bahwa ada perbedaan bermakna terhadap pelatihan yang dilakukan untuk petugas kesehatan di mana nilai $p<0,05$. Hal ini menunjukkan bahwa pelatihan pada petugas kesehatan merupakan strategi yang baik untuk mendeteksi penganiayaan usia lanjut di keluarga. Hal ini dikarenakan petugas kesehatan di puskesmas merupakan ujung tombak di dalammengetahui status kesehatan masyarakat di wilayahnya.

Penelitian yang dilakukan Duckhorn (1997) menjabarkan bahwa sebesar $14,6 \%$ terjadi penganiayaan fisik, $12,396 \%$ terjadi penganiayaan finansial, 7,796\% terjadi penganiayaan emosi, 0,396 terjadi penganiayaan seksual, 55,096\% terjadi pengabaian terhadap usia lanjut, 4,096\% tidak diketahui dan $6,196 \%$ terjadi penganiayaan lainnya. Bila dibandingkan dengan hasil penelitian ini yang menghasilkan bahwa sebesar $18,18 \%$ usia lanjut di keluarga mengalami penganiayaan fisik, 97,73\% penganiayaan emosi, 13,64\% penganiayaan seksual, $31,82 \%$ penganiayaan ekonomi/finansial, $61,36 \%$ pengabaian dan $29,55 \%$ mengalami penelantaran, maka penganiayaan yang terjadi pada penelitian ini relatif lebih tinggi dibanding dengan hasil penelitian yang dilakukan Duckhorn. Dan usia lanjut yang sering mengalami penganiayaan pada penelitian ini yaitu yang berumur 60 - 75 tahun, berjenis kelamin perempuan, bersuku bangsa Jawa, Agama Islam, tingkat pendidikan SD dan sudah berstatus janda/duda. Untuk itu perlu adanya penelitian lanjutan yang lebih mendalami faktor-faktor apa saja yang berpengaruh terhadap penganiayaan usia lanjut di keluarga.

Keluarga sebagai orang terdekat bagi usia lanjut harus mampu memfasilitasi usia lanjut untuk memenuhi kebutuhan dasarnya sehingga usia lanjut merasa bahwa dirinya tidak dianiaya oleh keluarganya. Untuk itu peranan keluarga dalam memotivasi dan memfasilitasi usia lanjut untuk melakukan aktifitas sehari-hari secara teratur dan memperbaiki gaya hidup sangat penting. Karena keluarga sangat berperan dalam tumbuh kembang anggota keluarga (Friedman, 1986). Keluarga juga berpotensi untuk mengatasi masalah sekaligus dapat menjadi sumber masalah pula bagi anggota keluarga termasuk usia lanjut, apabila keluarga tidak melakukan tugas kesehatan keluarga dengan baik maka penganiayaan dapat saja timbul dan dirasakan oleh usia lanjut.

Sehubungan dengan hal tersebut petugas kesehatan seyogyanya dapat diberdayakan dalam mendeteksi penganiayaan usia lanjut di keluarga secara dini, sehingga dapat meningkatkan kesehatan lansia, sekaligus menunjang program pelayanan kesehatan lansia di masyarakat. Oleh karena metode disusun oleh kelompok peneliti dengan masukan dari berbagai pihak, dan sudah diujicobakan, selanjutnya peneliti mengharapkan model ini dapat diintegrasikan dengan pelayanan Keperawatan Kesehatan Masyarakat (Perkesmas) di mana dalam pelayanan ini perawat/bidan bertanggung jawab membina masalah kesehatan prioritas di wilayah tertentu termasuk masalah kesehatan lansia; maka tenaga keperawatan tersebut dapat menjadi ujung tombak dalam mendeteksi penganiayaan yang dilakukan keluarga terhadap usia lanjut. Pada akhirnya diharapkan kesehatan lansia di masyarakat dapat dipertahankan bahkan dapat ditingkatkan.

\section{KESIMPULAN}

Model pendeteksian terhadap penganiayaan usia lanjut di keluarga dapat mendeteksi jenis penganiayaan usia lanjut di keluarga. Ditemukan perbedaan yang bermakna terhadap peningkatan pengetahuan dengan pelatihan pada petugas kesehatan $(\mathrm{p}<0,05)$. Identifikasi masalah penganiayaan usia lanjut yang dilakukan oleh petugas kesehatan yang mengikuti pelatihan adalah penganiayaan fisik sebesar $18,18 \%$, penganiayaan emosi sebesar $97,73 \%$, penganiayaan seksual sebesar $13,64 \%$, penganiayaan ekonomi/financial sebesar $31,82 \%$, pengabaian sebesar $61,36 \%$ dan Penelantaran sebesar $29,55 \%(\mathrm{HH})$.

* Penelitian didanai oleh Risbinkes tahun anggaran 2003/2004

** Etty Rekawati, SKp., MKM; Widyatuti, M.Kep., Sp.Kom; Poppy Fitriyani, SKp: Staf Akademik Kelompok Keilmuan Keperawatan Komunitas Fakultas Ilmu Keperawatan Universitas Indonesia 


\section{KEPUSTAKAAN}

Amendments to the Older Americans Act. (1987).

Duckhorn, E. (1997). Elder abuse. http:// www.nlm.nih.gov/medlineplus/elderabuse.html diunduh 2003

Friedman, M. (1986). Family nursing: Theory and assessment. $2^{\text {nd }}$. ed. Norwalk: Appleton Century - Croft.
Polit, D. F., \& Hungler, B. P. (2002). Nursing research: principles and methods (7th ed.). Philadelphia: Lippincott.

Skolniek. (1987). Administration elder abuse. http:// www.nlm.nih.gov/medlineplue/elder abuse.html.

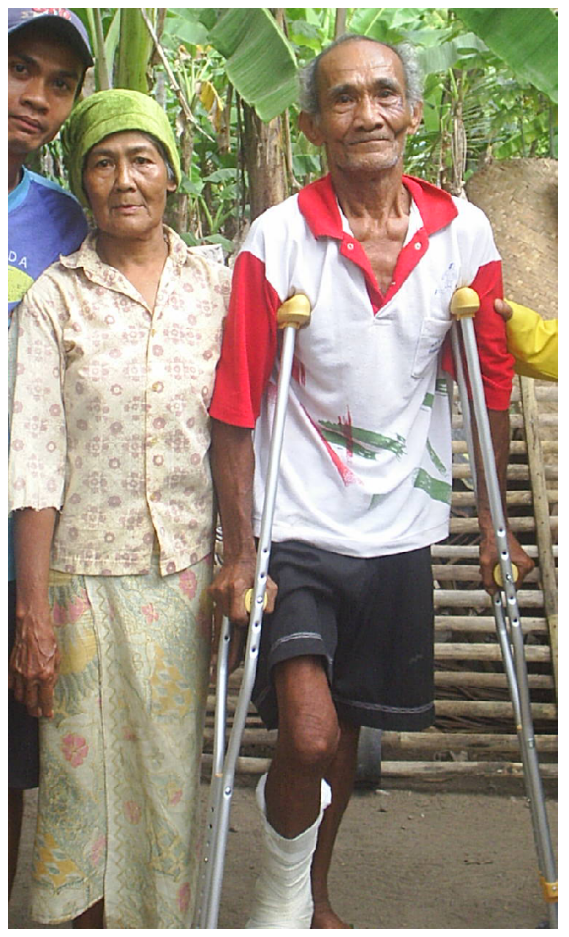

